\title{
Notes on militant populism in contemporary France: contextualizing the gilets jaunes
}

\author{
Winnie Lem ${ }^{1}$ \\ Published online: 21 July 2020 \\ (C) Springer Nature B.V. 2020
}

In the vast amount of writing that has appeared, the gilets jaunes (yellow vest) insurgency, journalists, academics, politicians, and pundits have been eager to pronounce on the morphology of a mobilization that has been puzzling in many ways. ${ }^{1}$ Almost as soon as it surfaced in France in October 2018, observers have hastened to define its features, so some writers have noted, by mapping their assumptions, hopes, or fears onto a mobilization that has confounded politicians, the press and the public alike. Many on the right, for example, see its potential as a force that amplifies the resurgent spirit of nationalism that has been eroded by the political and economic imperatives of globalization. Far-right parties, moreover, hope to ride the wave of its energy to gather support for their ultra-conservative political agendas. On the left side of the political spectrum, some harbor the hope that the gilets jaunes (GJ) insurgency will herald the coming of the next revolution. Others among the left fear its potential as a counter progressive and anti-revolutionary force. ${ }^{2}$ These pronouncements and speculations prevail despite the cautions issued against projecting one's assumptions, aspirations, and worries that render the mobilizations into something that observers want it to be rather than confronting the reality of what it is (Artous and Sitel 2019). Indeed, an optic that is too personal may be prone to distortion. Nonetheless, it seems that little work in the academy is devoid of projecting some aspect of the observer's political, ideological, aspirational, and emotional commitments that frame the questions that animate efforts to understand the world. So here I will try to make some sense of what this popular uprising is by focusing on some issues that warrant consideration, at least in my mind as an anthropologist who has undertaken fieldwork in France.

\footnotetext{
${ }^{1}$ See for example, https://www.contretemps.eu/gilets-jaunes-urgence-acte-kouvelakis/and then http://www. contretemps.eu/apres-commercy-gilets-jaunes/. Also Kouvelakis, S. (2019).

${ }^{2}$ These hopes and fears were expressed for example in a conference held on the GJ in 2019 attended by notable figures of the European left. In that event, Etienne Balibar enunciated the more fearful view while Antonio Negri posited a view which cast the GJ's as participants in building an optimistic future as a people's movement that contests capitalism. See Susser, (forthcoming)
}

Winnie Lem

wlem@trentu.ca

1 International Development Studies, Champlain College, Trent University, Peterborough, Ontario K9J 7B8, Canada 
These notes are based on observation, but not participation in the mobilizations of the GJ in Paris in 2019. While I chatted with some participants in the GJ movement, my conversations during fieldwork were undertaken mostly with those who have not been part of it and in fact who seem to disavow this militancy. They include members of Paris's Asian population who have been informants in my research on migrant livelihoods, the political economy of belonging, and class formations in urban France. Emerging from this research are reflections in these notes on how the contradictions in contemporary capitalism are refracted through the disparate aims of a militancy that builds social solidarities on the one hand while fostering divisions. I also ask the focus on the question of the relationship between the conjunctural forces in France and the emergence of movements that are populist in orientation

\section{Observations on the gilets jaunes}

To think through some facets of a mobilization that many suggest is unprecedented in many ways, I address 3 questions. The first question is concerned with historical antecedents that might shed light on the movement. I look into the past and ask what aspects of the GJ mobilization are shared with collective struggles that have erupted in France. I am provoked by the many writers who have made remarks, often in passing about its link to Poujadism, and I will try to expand on this association. The second question is concerned with issues of membership and belonging both in the movement and in the wider polity. So, it will reflect on the question of how representative is the GJ of the constituencies for which they claimed to speak. This facet of the question prompted me to follow the GJ in their Saturday mobilizations in Paris in the winter and spring of 2019. It also provoked me to reflect on the problems of the system of representational democracy that the eruption of the GJ exposes. The third is concerned with how the objectives that animate GJ struggles might suggest that grievances may be resolved. Here, I am especially interested in the nature of the challenges that are posed by the GJ on the capitalist state and state capitalism. For the sake of convenience, I have ordered reflections on these questions, in terms of $3 \mathrm{Rs}$ - retrospection, representation, and resolution. I begin first with a brief review of what we might know about the GJ by highlighting a few of its distinctive characteristics and then will move to address the 3 Rs.

\section{What we might know}

The movement of the GJ is distinguished by its scale, scope, and persistence. It has involved the longest series of public and mass protests in French history, having endured from November 2018 until March 2020. Its origins are dated to May 2018, when an online petition was posted by a woman who ran a small business in a southeastern suburb of Paris. The petition called for lower taxes on essential goods, the implementation of the citizens' referendum, lower pensions, and salaries of senior officials and elected officials. In October 2018, calls to oppose the rise in taxes on car fuel introduced by the government of Emmanuel Macron were added to these demands. This sparked the transformation of what began as an online protest in a digital forum into a series of collective actions that also unfolded in physical spaces. The first mass demonstrations took place on November 17 and attracted over 300,000 people across France, although the figures vary depending on the source and the week, the GJ actions mobilized from 90,000 to 1.3 million. It included participants in most of the 96 
departments in metropolitan France and 5 overseas departments (Guardian Sat 9 Feb 2019). Though still very active, the number of participants started to dwindle in late 2019, and in 2020, the last mobilization was staged on March 14, 2020. This was in defiance of government ban issued on the previous day that prohibited gatherings of more than 100 people in public places in response to the COVID pandemic. While public and the mass gatherings have been suspended, their activities continue on various social media platforms, including one that supports the online GJ magazine. ${ }^{3}$

Social media has been the main means through which information about GJ activities have been organized. Activities are announced on Facebook as well as many other social media platforms such as Démosphère https://paris.demosphere.net/. Information is also disseminated through local social networks through many and varied means, including by word of mouth (de bouche à oreille). There are two main forms of mass, collective action and both involve the occupation of public spaces. One involves marches, known as Acts, which involve weekly marches held on Saturdays. In Paris, participants in the marches rally at a meeting point then march along city streets through different neighborhoods.

The routes of the marches are pre-determined, announced publicly, and vary from week to week. The marches often end in a square, park, or field where participants rally again, socialize, debate, argue or disperse. The second form involves the occupation of roundabouts, usually located on the peripheries of towns and cities. These occupations interrupt the flow of traffic and of course disrupt the chains that supply the market and the economy. Also included are many spin-off initiatives such as the establishment of the journal of the GJ as well as the short-lived jogging jaunes on Sundays in Paris that was launched in early spring 2019. Curious to see how the Sunday event would unfold, I followed the joggers on their inaugural run which was attended by a very small group of roughly 20 women and men of varying ages and abilities. It also included one runner who pushed a participant in a wheelchair. The presence of a participant in a wheelchair was significant symbolically in terms of the composition of participants in GJ activities.

Participants in protests consist of a heterogeneous collection of people that have been difficult to define in terms of any single prevailing sociological category.

In terms of class, they have been referred to as members of the popular classes, incorporating different strata of the working and non-working poor. The non-working poor include pensioners, retirees, persons on social assistance, or with disabilities as the wheelchair participant in the jogging jaunes signaled, as well as many unemployed. The GJ have also been referred to as members of the working class who earn modest incomes with the average declared monthly household income at $€ 1700,30 \%$ less than the income for all households. But the GJ also include members of the petty bourgeoisie who own and operate businesses in France. For those GJ who are engaged in paid work, the core participants seem to be those who hold positions situated at the lower end of the occupational hierarchy in a very diverse labor market. They work as truck drivers, health care workers, artisans, taxi drivers, teachers, laborers, personal, care workers, nurses, waiters, cashiers, and secretaries. With wages that are commensurate with low status, the GJ also encompass many who work as part of the contingent labor force in the "gig" economy. Some of these were food delivery workers, uber drivers, manual workers, seasonal laborers, and handypersons. In contrast, other participants who are engaged in paid work are employed in white collar jobs as mid-level managers in such organizations

\footnotetext{
$\overline{3^{3} \text { https://www.gj-magazine.com/gj/ }}$
} 
as insurance companies, real estate agencies, and pharmacies. In terms of sociodemographics, observers have noted the uncommon age and gender composition of participants in such mass mobilizations. The average age of the participants seems to be between 45 and 60 and roughly $45 \%$ are women.

While there is considerable heterogeneity, one unifying feature is that many participants have never participated in popular protests and generally tended to eschew collective action. This is particularly the case amongst owners and operators of small businesses or members of the petty bourgeoisie. Another significant unifying feature is that they position themselves as peripheral in sociopolitical, economic, and also geographic landscape of France. Many participants in the Paris Acts actually live and work outside the city, in surrounding suburbs, as well as small towns, rural, and peri-urban settlements. These participants make a weekly drive into the center of cities such as Paris to join in the marches and rallies. Beyond Paris, of course, the GJ have a strong presence in the small towns and villages in France provinces. Inhabitants of some of these provinces have for a long articulated a sense of marginality which is coded in forms of regional nationalist politics. I will return to this later in these notes.

Amongst some of its participants are that many and varied supporters that include and national and international cohort of intellectuals, academics, activists, and university students. Many of the latter of course are undertaking research for scholarly papers and theses about the mobilization. One of these was a student who was interested in its possible analogs with the Umbrella Movement and pro-democracy protests in Hong Kong. In Paris and in many of the cities in the provinces, the GJ have also gathered up some controversial figures. Some of these are provocateurs, mostly young men dressed in black clothing masks and hoodies, generally thought to be members of the Black Bloc. These figures were often engaged in such tactics as defacing symbols of wealth, spraying buildings with graffiti, and breaking windows of luxury goods retailers, banks, and insurance companies. The symbolism of such acts of course was not very subtle. In many of the rallies that took place in squares such as the Place de la République in Paris, many of these young men clustered to form a cohort that would taunt the police who responded by hurling tear gas and stun grenades. Many of these provocateurs were suspected to be undercover cops and indeed many plainclothes police are interspersed amongst the protesters. They often moved freely and openly between the protestors and police, stepping in and out of vans that block roads and intersections.

The mobilization of the GJ is further distinguished by two other related features. There is a lack of commitment to any single ideology or political philosophy and this is combined with a deep commitment to horizontalism. There is a general abhorrence of hierarchy, and the GJ have made much effort to create an impression that any structure that required leadership and hierarchy is anathema. So it has no set leader and the movement is not supported by any formal organization. However, this does not mean that it lacks organization and structure. Local and regional committees are struck to organize gatherings, assembles and there is also a federation of assemblies. "Assemblies of assemblies" have been organized by a central committee of GJ and these meetings have resulted in the creation of the official charter of the GJ (la Charter Oficielle des Gilets Jaunes) (Image 1).

The charter contains a set of demands that are as heterogeneous as their participants, extending from banning speed cameras to withdrawing France from NATO. However, the core of their claims focuses on economic justice in the light of the injustices and grievances that are experienced by those who constitute themselves as marginalized, underprivileged, 


\section{OFFICIAL CHARTER OF VELLOW VESTS} 25 proposals to coll an end to the crisis

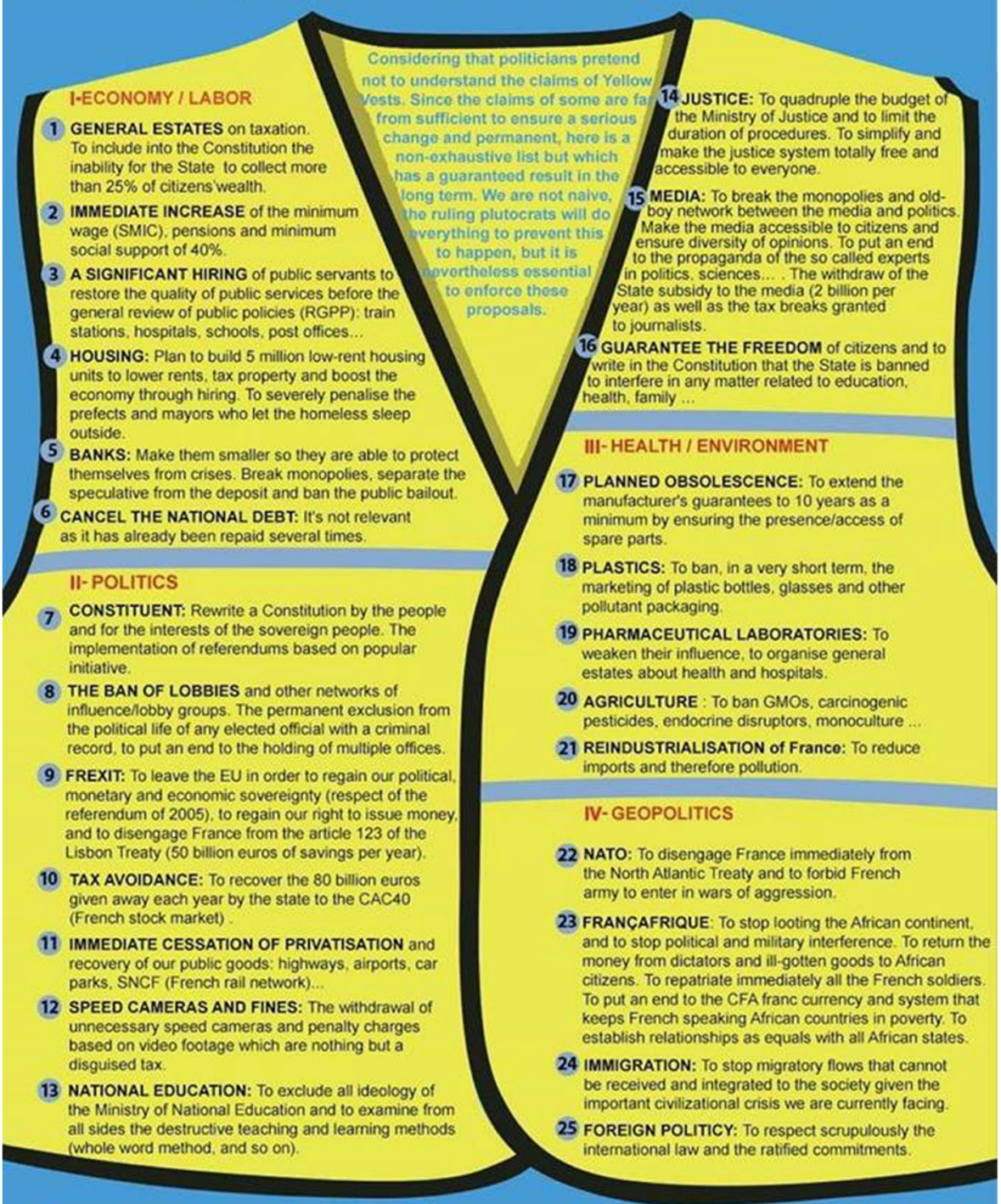

If applied these 25 proposals will immediately change the daily life of the French people. The articles 9 and 10 of this Charter alone can bring up to 130 billion euros per year to the Tresuary. France is a rich country, with brave and hardworking people, no one should be living in poverty.

Image 1 Official charter of the gilets jaunes (source https://www.lelibrepenseur.org/giletsjaunes-charter-of-25claims-of-yellow-vests/)

impoverished "people." Such people stand in contrast to a privileged monied and powerful "élite." Indeed, their manifestos and proclamations, the lines of opposition are drawn in dyadic terms as the people vs the élite. Also, the common people are venerated while élites are vilified 
${ }^{4}$ This valorization of the people and denigrating the élite have translated into a demand to create a citizen's referendum as a forum for popular sovereignty. With an oppositional politics that has these features, the GJ mobilization is the embodiment of a militancy that is populist in orientation $^{5}$ Militant populism is not unprecedented in the extensive history of collective protest amongst the notoriously "contentious" French (Tilly 1986).

\section{Retrospection}

In looking into the past the GJ mobilization resonates in several respects with a populist movement that emanated in the 1950s from France's regions and small towns. The movement came to be known as Poujadism named after Pierre Poujade, a small business owner, who initiated a tax revolt in 1953 in a small town in the department of the Lot in southwestern France. ${ }^{6}$ This revolt began as Poujade, and a small group of people prevented government tax inspectors, whom they called "le Gestapo fiscal" from investigating tax fraud in small businesses. ${ }^{7}$ Called by some, a movement of the petty bourgeoisie, Poujadism eventually spread throughout France. This revolt galvanized the support of artisans and small shopkeepers whose ire was directed initially toward the tax system, particularly the income tax system, and then grew to focus on the French state and its visions for economic development and modernization in the Postwar era. Support for Poujadism was so strong that Poujade created a political party, the UDCA (Union of for the Defense of Shopkeepers and Craftsmen) in 1953. It mounted a list of candidates in the French elections in 1956 and secured 52 seats in parliament.

The GJ mobilization was also ignited by a protest against taxes, sparked by a fuel tax introduced by the French government as part of a general effort to reform the tax structure. This tax was seen to have an adverse effect on the middle and working-class strata of the French population as well as people in the peri-urban, suburbs, and rural regions who relied on motor transportation for work and access to consumer goods. The tax was withdrawn in December 2018 but not before the protests became widespread and grievances expanded to other facets reform programs pursued by the French government. However, unlike the Poujadists, the GJ have not formed a party or at least not yet, and it reject attempts by individuals who emerge and claim to represent them. Yet, despite this commitment to horizontalism, several key figures have emerged and were elected to act as spokespersons for the GJ. Moreover, several individuals have appointed themselves as representatives of the GJ and ran for seats in the European parliament. They mounted campaigns amidst much opposition from the ranks of the GJ and were resoundingly defeated in the EU election in May of 2019.

The GJ and the Poujadists both emerged at conjunctures characterized by much political turbulence and economic uncertainty. Poujadism arose as France was emerging from Vichy rule and 23 governments had risen and fallen since 1945 and the end of WW2. The nation had also suffered many major humiliations on the global stage. It lost its colonial possessions in South East Asia after its defeat in 1940, Dien Bien Phu, and France also failed to regain control of Suez from Egypt late 1956. The post-war era was also beset by the turbulence and

\footnotetext{
$\overline{4}$ see Mayer, N., Rockhill, et al. (2019). Also see Bart Bonikowski and Noam Gidron 2016)

${ }^{5}$ See Hoffman, Stanley 2008: 102.

${ }^{6}$ The GJ have been described derisively as a Poujadist movement especially by some segments of the left. (Wilken 2018)

${ }^{7}$ Shields, J. G. (2004); Hoffmann, S., Des Accords, M., Hurtig, S., Du Rostu, J., \& Meynaud, J. (1956).
} 
instabilities of a war-torn economy. To regain stability and to stave off the appeal of Soviet socialism, transnational capital was pumped into France though the Marshall plan for restructuring the French economy, which added to the turmoil and chaos. It was far from obvious that in the mid-1950s, France was on the cusp of the 30-year period of economic growth from 1950 to 1980 that later to be known as "les trente glorieuses," during which a welfare state based on Keynesian economic principles would be constructed. ${ }^{8}$

The GJ have also appeared at a tumultuous time in France that has extended from the 1980s and continues into the 2000s. This is a period of time that some have called the 30 pitiful years (les trente pitieuses) (Bavarez 1998) when programs of neo-liberalization based on Hayekian economic principles provoked a political and economic shift "state-managed capitalism" to "financialized capitalism." Such programs were rolled out to stabilize an economy suffering the crises of slow growth provoked in part by the oil crisis in 1973 and the efforts by governments who worked in league with international financial institutions to create globally integrated economies. In France, neoliberal reforms were initiated in the 1970s with a moderate approach to the privatization of public services, industry, and sales of public assets. But it became more aggressive as the twenty-first century approached. So reforms to pensions deepened, the labor codes were dismantled, which weakened the rights of employees, workers, and unions. Privatizations became deeper and more extensive. Also, welfare entitlements that benefit the most disadvantaged segments of the French population were terminated. Meanwhile, tax cuts were extended to private corporations and those who run them. The tax on fuel was introduced in this context, which was perceived by the GJ and furthering and assault on the disadvantaged. Introduced to remediate some facet of a climate crisis, it is an example of neo-liberalization in its ecological variant. ${ }^{10}$ Introduced to remediate some facet of a climate crisis, it is an example of neo-liberalization in its ecological variant. The rise of the GJ underscores the fallacies that are embedded in a strategy of socializing solutions to problems that have been created by private and corporate capital. For these, strategies and their tyrannies simply perpetuates the cycle of social and economic crises the example of many nations in the global south show. For the reforms and programs of austerity that have been applied in France were first tested in the context of the debt crisis of the 1980s in nations of the global south. Referred to as structural adjustment programs imposed by international financial institutions (IFIs) upon developing countries, governments in Africa and Latin America implemented privatizations, deregulations, the termination of protectionism and subsidies in social provision and food production. The population at large, then, bore the brunt for crises of slow growth and of servicing sovereign debt and were drawn into IFI's agendas of creating a liberalized global economic order.

The foundation of this global order was of course was initiated in the aftermath of World War 2 when institutions such as the World Bank and the International Monetary Fund were formed largely under the aegis of the USA to facilitate international financial transfers for economic development. This was also a period of the reconstruction of European nations and the financial infusion that came to France from the US-backed Marshall Plan was combined with the Monnet Plan to direct the course of a program of modernization. This program involved the building an economy through rapid industrialization supported by urban

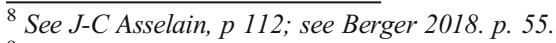

${ }^{9}$ Fraser, Nancy (2017)

${ }^{10}$ The French approach of "pragmatic neoliberalism" stood in contrast to the American or British approach of aggressive cuts in social spending, tax cuts, and rapid deregulation of industry. See Prasad (2005), Smith (2004), Fourcade- Gourchinas, Marion and Sarah Babb (2002)
} 
development. These economic plans provoked a backlash amongst certain segments of France's population. These segments included many small farmers in regions such as Languedoc where I undertook my first field research on agrarian change and regional nationalism $^{11}$ (Image 2). Indeed, in the legislative elections of 1956, support for the UCDA party was very high in Languedoc (Image 3).

Languedoc is a region of mono-crop viticulture dominated by small-scale owner-operated family farms. Some of the small farmers were fervent advocates of regional autonomy and separatism citing centuries' cultural, economic, and political domination of the north over the south and of the center over the periphery. This was articulated as the domination of the people of the langue d' oil over the people of the langue d'oc, who inhabited the cultural and vague physical space of Occitania (l'Occitanie). ${ }^{12}$ Many of the small farmers who own and operated such holdings were also firmly embedded in the politics of agrarian populism. This form of populism valorized notions of small-scale, local, artisanal production, and vilified large-scale modern industrial farming. In the post World War 2 era, this vilification was manifested in much opposition to the plans to modernize the agricultural economy.

I suspect that many such farmers were very likely sympathetic to Poujadism, for the Poujadists were very much opposed to modernization, as well as industrialization and urbanization. ${ }^{13}$ They also displayed a propensity to be anti-American and nationalistic adhering to the view that modernization American style ran counter to French national interests and identity ${ }^{14} \mathrm{~A}$ form of nationalism that emerged amongst the Poujadists translated into xenophobic tendencies which particularly targeted France's Jewish population. Pierre Mendes France, the socialist prime minister of France who also served under de Gaulle, was a particular target. Such xenophobic tendencies brought the Poujadists into alignment with the remnants of the Vichy regime that had broken up by 1950 and its supporters dispersed. So, Poujadism also gathered up the likes of Jean Marie le Pen (the founder of the extreme-right National Front in France) and in fact launched Le Pen into politics. He was a member of the youth wing of the UDCA, and in the 1956 parliamentary election, he secured one of the 52 seats won by the Poujadist party.

It is noteworthy that in the Languedoc region of France is one of the areas where support for the FN has grown over the course of the past few decade (Image 4).

Issues of xenophobia and nationalism bring me to the questions of representation and perhaps more at issue, the failures of representation in the movement, and in the wider polity.

\section{Representation}

In principle and practice, whoever dons a Yellow Vest is considered to belong to the GJ movement. Who then wears these vests? What are the parameters of belonging in this movement? The movement does gather up a wide swath of the French public. But how wide is this swath? These questions prompted me to follow the GJ in their Saturday Acts in Paris in

\footnotetext{
${ }^{11}$ Lem, W. (1999).

${ }^{12}$ Langue d'oc vs langue d'oill refers to a distinction in the way that languages pronounced "yes" either as $o c$ in the south of France or oill in central and northern France. The line the divides speakers of the langue d'oil from the langue d'oc is blurry but generally thought to run from Grenoble to Bordeaux.

${ }^{13}$ Fitzgerald, S. (1970)

${ }^{14}$ Shields, J. G. (2004).
} 


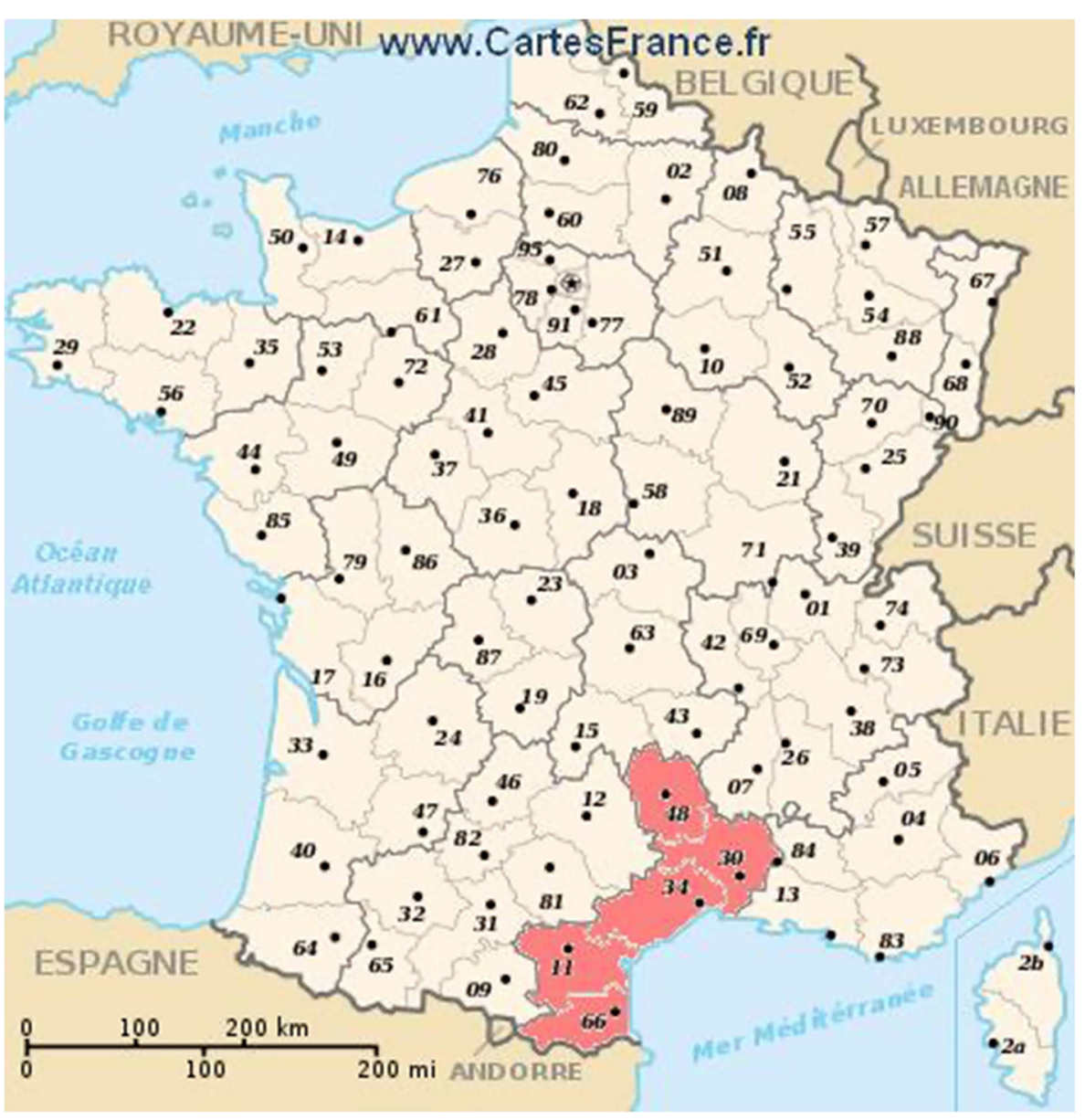

Image 2 Map of Languedoc in France

2019 and I got much caught up in marching and chanting what has become a rousing anthem: ${ }^{15}$

On est là, on est là!

Même si Macron ne le veut pas, nous on est là!

Pour l'honneur des travailleurs et pour un monde meilleur!

Même si Macron ne le veut pas, nous on est là!.

(We are here, We are here, we are here!

Even if Macron does not want it, here we are!

For the honor of the workers and for a better world!

Even if Macron does not want it, here we are.)

My trailing of the GJ and observations of participants in the marches also prompted me to ponder the valences of the "we," in the light of how two mobilizations unfolded in the streets of Paris.

$\overline{15}$ This chant is a version of hymn of the railway workers (hymne des cheminots) that was often sung during strikes and other collective actions. 


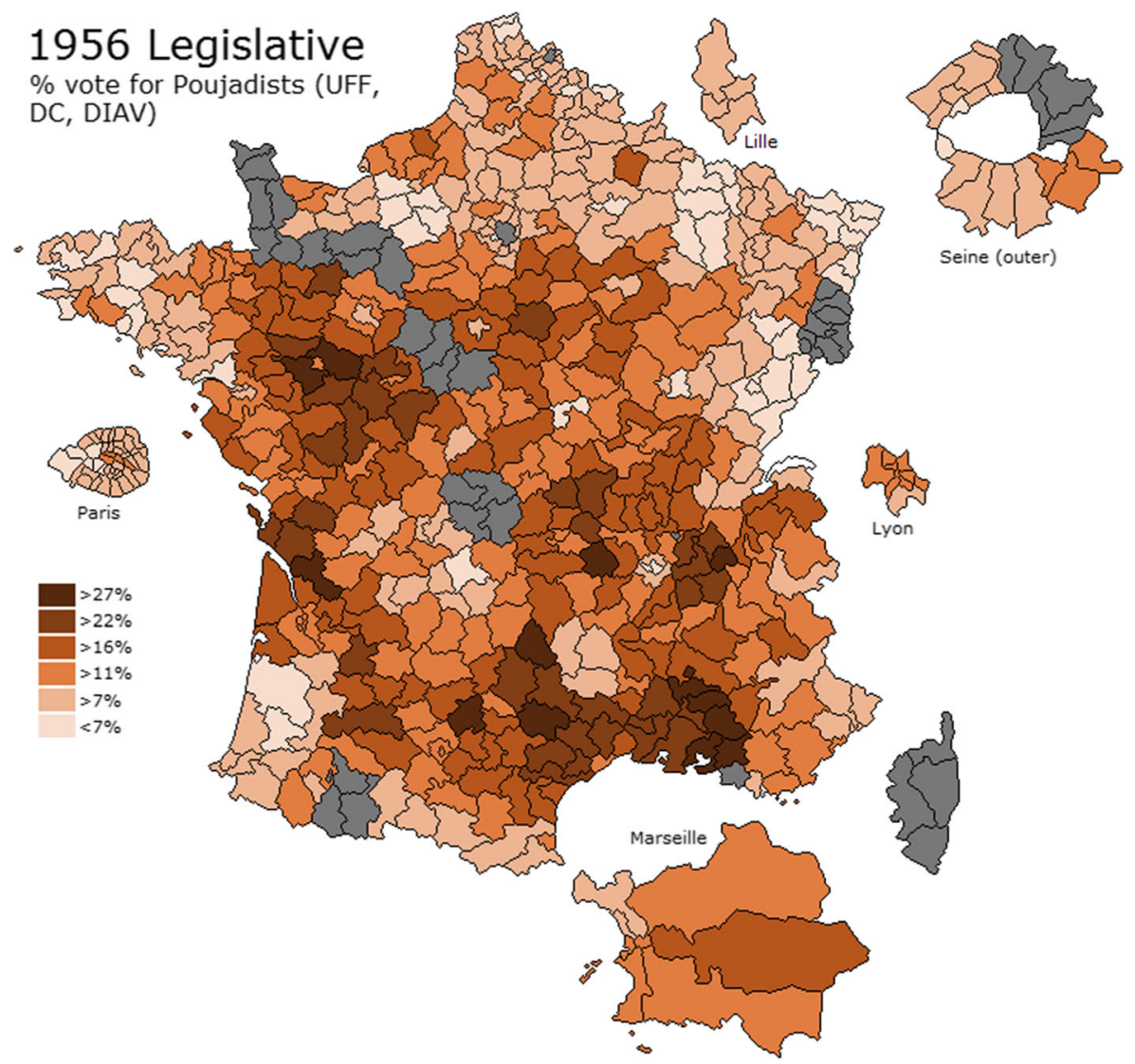

Image 3 The legislative elections of 1956

\section{The rise in National Front support}
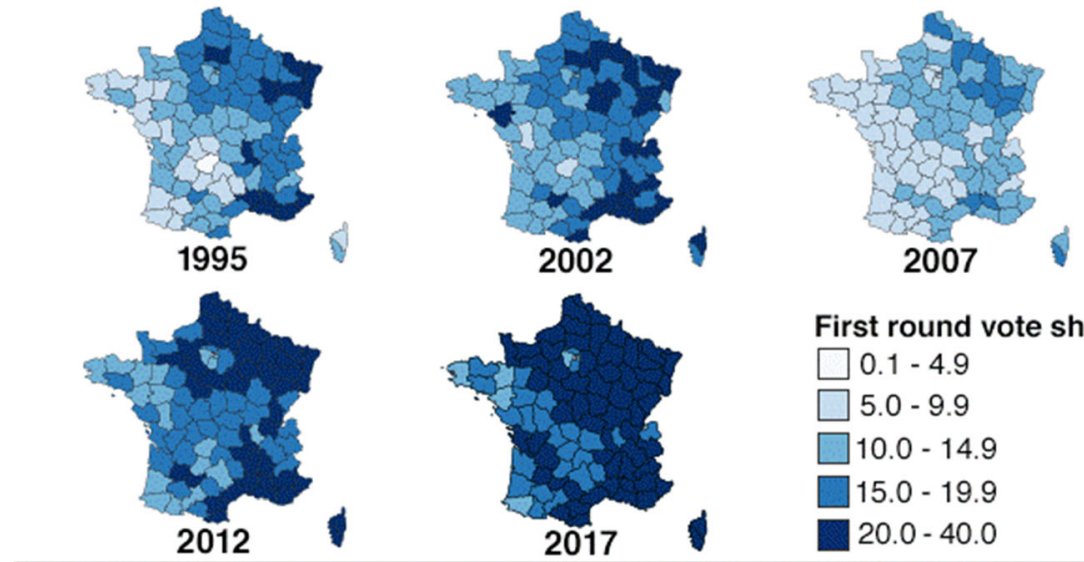

Source: French government

BBBC

Image 4 National Front support in France 1995-2017 
One was the march through the neighborhoods on the Blvd. de Strasbourg on the right bank of Paris. This is a neighborhood filled with businesses run by the Franco African population of Paris.

The other was the march through Ave. de Choisie, in one of Paris's Chinatowns on the left bank. The valences of "we" became abundantly clear in the spatial politics of the marches and evoked the insights of Lefebvre (2003) and David Harvey's (2012) on spatiality in urban politics and the patterns of who moved through the city and how. In both marches, I noted how the different social divides and cleavages that prevail in urban France are refracted through the patterns of occupation and movement through the public spaces of roads and sidewalks. The roads were a central conduit for a population of mostly white participants. People of color either stood on the sidewalks and watched or simply ignored the GJ and went about their daily business. In the march along the Blvd de Strasbourg, Franco-Africans stood on the sidelines, watched the marchers as they passed by (Image 5). Many smiled rather uncomfortably as some amongst the GJ protesters beckoned bystanders to join with a hand wave. I asked one bystander why he was rejecting the gesture from the GJ. The gist of his reply was that he did not see himself reflected in the GJ.

Another person who stood on the sidewalk remarked on the marchers saying: Tout ce que je vois, c'est une vague de visages blancs avec quelques points de couleur (All I see is a wave of white faces with few dots of color).

In another march through the Chinatown on the Avenue de Choisy, Asian business owners hastily locked doors and barricaded their windows as soon as the police vehicles appeared announcing the imminent arrival of the GJ. Most Franco-Asians on this avenue, like the Franco Africans on the Blvd de Strasbourg, simply let them GJ pass by, did not respond to invitations to join in the march, and simply carried on with their daily activities.

My fieldwork on the occupation background of many of Paris' Asians population seems to suggest an affinity between their concerns and the concerns of the GJ. Many of Paris's Asian population are small business owners, truck drivers, care workers, pharmacists, artisans, and taxi drivers Also, a good number of Asians live and work in the urban peripheries and outer

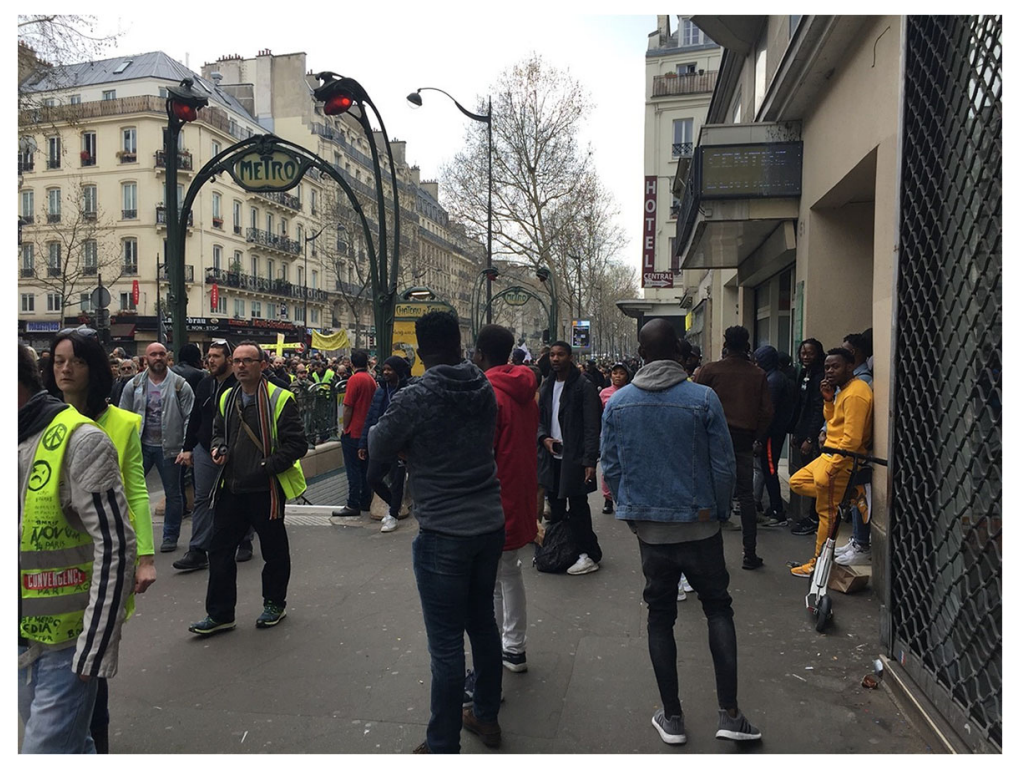

Image 5 The GJ March-Blvd de Strasbourg 
suburbs of Paris. Yet, on the whole, they seem to reject the GJ. Many Franco-Asians have historically avoided political activism and this may also in part explain their lack of engagement in a struggle that in which certain aspects of their economic interests are served.

Yet several incidents in recent years have roused them into taking up different forms of collective action amongst a normally "quiescent" population. Many of these are acts of "militant particularism" 16 in which members of the Asian population have risen up, for example, in protest against racism which targeted the "Chinese." Most recently, Franco Asians have been mobilized to contest the predictable rise of anti-Asian hostility due to COVID 19 and the re-emergence of the heinous language of the "yellow peril" at least in taking forms of digital activism.

In talking about the GJ, I have joked with some of my colleagues in France as well as some Asian informants, who stood on the sidelines..., "où sont les jaunes dans les gilets jaunes?" Roughly translated: "where are the yellows (yellow people) in gilets jaunes?"

The joke sounds better in French.

The jaunes appeared during Chinese New Year in February 2019 (Image 6). Two men who donned a yellow dragon costume danced their way into the march and created a spectacle by taunting the riot police. This spectacle was that proverbial exception to the rule.

It is a source of bemusement to many of my informants that the GJ mobilizations have arrogated the color yellow and have been referred to as the new "Yellow Peril" in several articles and commentaries in the press. ${ }^{17}$

While in the protests, many demonstrators carried anti-racist and pro-immigrant signs and placards, many members of France's ethnic minority and migrant populations seem to disavow the GJ. So very few sported the yellow vest. In my chats with some members of the migrant and ethnic minority populations, there were worries about the xenophobic proclivities amongst some of the participants and ideological ambiguity around the question of migration. This ambiguity is reflected in the widely publicized GJ charter which contains a demand to "prevent migratory flows that cannot be accommodated or integrated, given the profound civilizational crisis we are experiencing." The coupling of migrants with the profound civilizational crisis reinforces the suspicion held by many migrants that xenophobic currents prevail amongst the GJ and this has been reinforced by the widespread reportage of anti-Semitist attacks attributed to its members. ${ }^{18}$ Such worries about racism, so some migrants with whom I chatted have suggested the GJ appears to be "a white people's protest." Such white people are often referred to as the "Français de souche" (people of French stock), an invidious term often used assert the boundaries between "the French" and the "non-French" or "us" and "them" in the fraught politics of belonging. This view amongst informants that the GJ seem to be a protest largely of the "Français de souche" is prevalent despite anti-racism placards that are evident and disclaimers made by many GJ in the press that run counter this view. These divisions have condensed into specters of color through which larger ideologies and practices of belonging under the strain of neo-liberalization are refracted. ${ }^{19}$ Such specters and

\footnotetext{
${ }^{16}$ See Harvey, D., \& Williams, R. (1995)

17 Wilkin, P. (2020)

${ }^{18}$ A study produced by the Fondation Jean Jaures showed that $50 \%$ of those who participated in Yellow Vest protests said they believed in a "global Zionist conspiracy." https://jean-jaures. org/sites/default/files/redac/commun/productions/2019/0220/rapport_complot.pdf

${ }^{19}$ Although xenophobia and anti-immigration attitudes and values have been around for a long time they have reactivated or leveraged into greater salience by the economic strains that neoliberal globalization has imposed on different segments of the population. Political shifts in national politics makes these members of the population feel even more marginalized and looked down on. Amongst these political shifts, perhaps the most painful is the rise in social status of the very groups to whom poor whites once felt superior and the conviction that these groups are rising because of favoritism from national government.(See Berger 2017)
} 


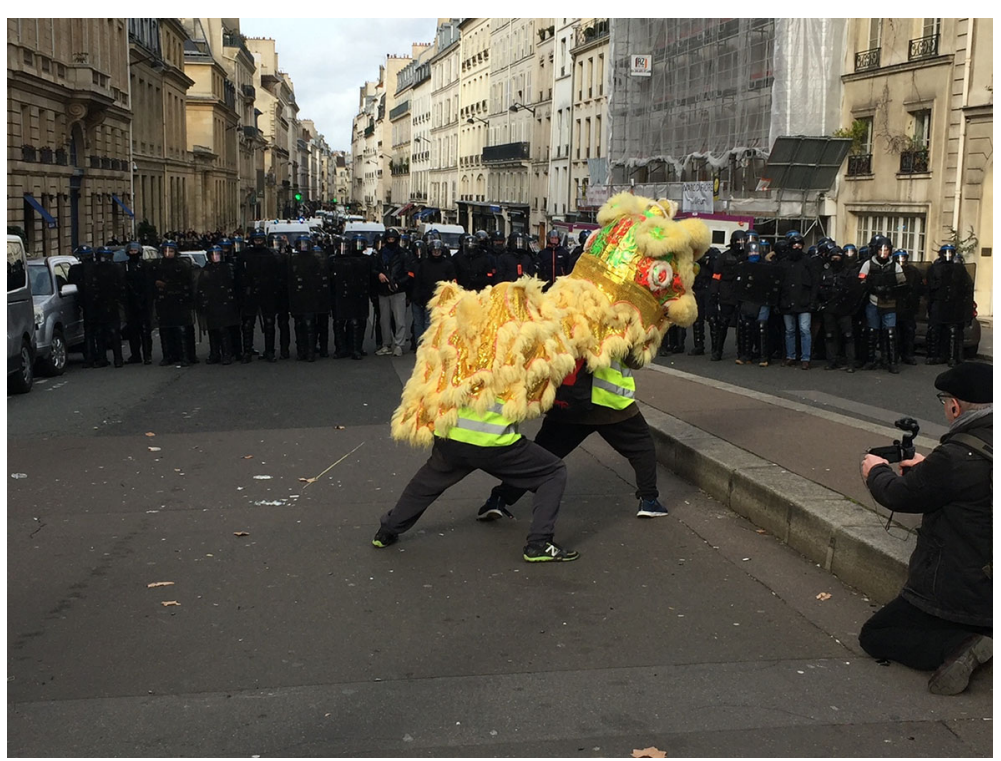

Image 6 Chinese New Year February 2019

their resonances have been made evident in the spatial politics in the GJ mobilizations. These specters suggest that rather than building important solidarities, the GJ seem to reinforce the migrant non-migrant divide and to emphasize divisions by color.

The specter of color is indeed very much embedded into the GJ insurgency and the mobilizations that have grown around them. Collective actions that have arisen to repudiate the GJ have also adopted a color. The foulards rouges (red scarf) movement, emerged as a counterfoil to the GJ. It consisted of a quite disparate collection of people and at its height, the mobilization drew only 10,000. It fizzled out after a few demonstrations in late 2018 and early 2019. The GJ have also spawned a parallel militancy - the Gilets Noirs. ${ }^{20}$ The GN are a collective of undocumented migrants in France whose slogan is "black with anger." It is a mobilization that has emerged to protest the repression of undocumented migrants, detention centers, the emergence of a deportation state, and the conditions of work for migrants in Paris who face racism, terrible living, and working conditions. These are not issues addressed by the GJ.

While nationalist and xenophobic elements seem to be present amongst the GJ, the GJ themselves have also rejected any attempts by the far-right and all political parties to represent them. The ideological programs of the far-right often ranged from the conservative corporatists to outright fascism as well as anti-Republican, anti-parliamentary, and anti-liberal sentiments. However, like the Poujadists before them, the GJ seem to lack an ideological paradigm. Also, like the Poujadists, the GJ simply and viscerally focus their attacks on the élites that controlled the Republic. The élites under attack by the Poujadists were a vague assemblage of French Third and Fourth Republic politicians, capitalists, and left-wing intellectuals (Berger 2017). In a similar vein, the GJ focus their attacks on "the élite" that is understood to include the rich, well-educated professionals, banks and insurance companies and globally connected big business, transnational companies who have done well out of the forces of neoliberal

${ }^{20} \mathrm{https}$ ://www.mediapart.fr/journal/france/200719/les-gilets-noirs-un-collectif-radical-qui-veut-relancer-lesluttes-de-sans-papiers?onglet=full 
restructuring of economies. So, the GJ direct their anger at the state and the failure of its political system to ensure their well-being and they are fervent in their demand for the resignation of a president whom they call a "president of the rich." The emergence of the GJ underscores the flaws of a democracy that operates in a world divided by a social and political class and in which the state operates in league with capital to ensure the power and wealth of the élite.

This path toward strengthening the position of an economic élite is paved by a selfreproducing political élite. In France, this is particularly reinforced by the phenomenon of the rule of the "ENArques," graduates of the Ecole Nationale d'Administration (ENA). This is a bastion for the education of the privileged, training members of the élite to become members of the ruling class. Graduates of the ENA tend to monopolize positions of power as ministers, senior civil servants, industrial magnates, and presidents. Like many presidents before him, Macron is a graduate of the school. Such institutions select and set the rules for ensuring the ruling class sustains its power and in a system of representative democracy. The representation by the élites is of course a way of constraining and limiting democracy and power from being extended into wider segments of society. So the result is that the interests and claims of those classes are largely invisible and appear irrelevant to the agendas of those in power. Wearing a jacket that is yellow and fluorescent is apposite, not only because it is a militancy that was ignited by an issue related to motor transport, but these jackets are mandatory for motorists to carry in their cars to be worn as a safety measure to make motorists visible on the roads in case of accidents. Worn by participants in the mobilization, the yellow renders visible a segment of French society that has felt itself to be invisible to the gaze of state and their mobilization signal the failure of the state and its institutions to represent them. In an attempt to stem the wave of GJ protest, Macron announced in April 2019 that he will close the ENA.

However, it is unlikely that the shuttering of one institution will terminate the power of the ruling class under capitalism nor change a system that has contributed toward a situation in which the top $1 \%$ now own $20 \%$ of the nation's wealth and are increasing their wealth more quickly than comparable élites in any other country, including China (Wilkin 2020). So in the view of the GJ, this political system and its economic model have not only generated wealth for the élite but also failed to represent the interests of those sidelined by the current economic and political system. Their rage emerges from the failure of political institutions as well as political parties and also unions to represent the interests of those in situations of much economic vulnerability. The GJ are persistent in their opposition to the rule of élites, and their attacks and grievances are focused on the injustices that this political system generates. This raises the question of the aims of the GJ and how they foresee that their grievances might be resolved.

\section{Resolution}

In focusing on the questions of resolution, my interests lie in asking what are the desired ends of this militancy and what might they tell us about the movement. A consideration of these questions also has at least 2 facets. The first is the issue of the mobilization and tactics of the GJ itself in relation to the economy of capitalism. The second focuses on the endpoint GJ agency whether its aims are to reproduce the capitalist state and indeed state capitalism or challenge it. 
The grievances of the GJ are focused overall on economic injustice and their rage emerges from the difficulties that are experienced in the attempt to reproduce human life. Such difficulties have been exacerbated by the programs of neoliberal restructuring. This suggests to me that they are engaged in a struggle for social reproduction and their contestation focuses on the production of people and not the production of things (Katz 2001; Harris and Young 1981). The mobilizations of the GJ are clearly not organized around sites of where the production of things is located in the circuits of capitalism. They also occur outside of workplaces and working hours, mostly on the weekend at traffic circles, organizing blockades that alter and slow down the circulation of goods and people. The GJ mobilization then may be differentiated from those that focus on the direct wage and the conditions for exploiting the labor force within the workplace (Paye 2019).

This division was evident in the spatialities of the Mayday March held in Paris in 2019. The GJ participated in this annual parade which is organized by the major unions in France such as the Force Ouvriere and the General Confederation of Labor (Confédération Générale du Travail). The GJ marched as a cohort in front of the unions and the union marshals carried rope to maintain a physical distance that separated the union participants from the GJ. Also, the march is usually peaceful, but in 2019 , it took a violent turn when GJ clashed with the polices. So against the optimistic view held by some members of the left that the GJ is a form of class struggle, it is a militancy that cannot be seen in a very clear sense as a struggle of labor against capital. Their demands target the state and not employers.

The GJ then are not opposed to the republic, the state, and capitalism but are agitating to reform the capitalist economy in ways that serve the interests of people within the borders of the French nation who have been marginalized. As a struggle for economic justice, the goal is to ensure that a moral economy will prevail. The GJ do not take issue with an economy based on the accumulation of capital, but they argue that the gains of accumulation should be distributed and not hoarded. Such redistributive justice can take many concrete forms. The GJ have argued that gains in the current economic system must be used to compensate those who have been thrown out of jobs or that to ensure that those who have been ejected from one industry can be absorbed into employment in other more promising sectors of the economy. If these guarantees are not possible, then those who are out of work and deprived of a means of making a living must be compensated by the government and the political system. To enable this form of economic justice, they propose a form of direct democracy Référendum d'initiative Citoyenne (RIC) citizen's referendum which is a proposal for a constitutional amendment to permit the consultation of the citizenry to limit the power of political bodies to propose or abrogate legislations. ${ }^{21}$ While this poses a limitation on representational democracy, the focus on popular sovereignty through a form of direct democracy does not replace it.

Redistribution, then, is the economic endpoint of struggles, and such an endpoint would enhance the ability of people to sustain life for at minimum; purchasing power in a commodified economy will be increased. The struggles of the GJ are focused on reproduction, not only of people but are also linked to the reproduction of "the people" as a nation. The reproduction of human life is achievable if France withdraws from the European Union and so an emphasis that is placed on FREXIT, the French version of BREXIT which will enable a renewed emphasis on the national economy for the nation and its people. Globalization has exacerbated the problems of reproduction, and so in the agendas of the GJ, there is opposition to global integration and a renewed emphasis on the galvanizing and reproducing the nation and its

$\overline{\left.{ }^{21} \text { Zoe Lauwereys (10 December } 2018\right)}$ 
people. The obscurities contained in the rhetoric of "we" and "the people" combined with the ambiguities of the GJ position on ethnicity and migration, juxtaposed against the demand to end the "civilization crisis" has raised concerns about what such a struggle for reproduction means for people of color, racialized populations, and migrants. This is of course not insignificant at a particular moment of history in 2020 when struggles to end racism have proliferated around the globe.

Final reflections

In much of the literature that has emerged on the GJ, it is almost de rigueur to add a speculative note that considers outcomes, effects, and the future of the movement itself. These speculations are often premised on the many templates that history has offered to make sense of this militancy. There are those who have looked back at collective struggles in France's past and have made comparisons between the GJ and Jacqueries that took place in medieval Franc $^{22}$ In these jacqueries, peasants rose up often violently in protests against tax offices and local landowners. Others have suggested that the GJ resonates with the 1789 Revolution, in which struggles were initiated between those who favored direct democracy and those who favored representational democracy led by elites in the formation of the new republic. ${ }^{23}$ Still others have forged a link between the GJ to movements outside France, and the GJ have been likened to the Chartists. Chartism was a transclass movement that arose in England in with the publication a people's charter, in May 1838. The chartists included artisans, traders, managers, and small shop keepers close to the working classes, and their charter, petitions, and collective actions led to parliamentary reforms that allowed unpropertied men to vote. ${ }^{24}$

Poujadism is another template drawn from history and in making the comparison between GJ and Poujadism, I have stressed that they are movements that seem to be dominated by several absences and negative qualities. There is a striking absence of an ideology, program, doctrine, or even a notion of utopia. The participants inhabit an affective world that is negative and seem to subscribe to a world view that is reductionist in its adherence to a Manicheanism which sees systems institutions, practices, and people in terms of a dualistic division between good and evil. Moreover, the mobilizations are propelled by anger and grievances. While anger and a sense of injustice fuels most social movements, the participants inhabit an affective world that is particularly negative. Such negativity, reductionism, and anger render such movement particularly prone to xenophobia and an ethno-nationalist outlook. So, if some speculation is in order, the negativity, Manicheanism, and lack of vision and more significantly lack of a coherent ideology will likely be the undoing the GJ like the Poujadist before them. For Poujadism disintegrated in 1958, and its participants were gathered up into movements, organizations, and parties with more coherent ideologies, programs as well as institutional support.

I have also referred to the movement of the GJ as militancy that is populist in orientation. Populism is of course a much-vexed concept. It is protean in nature and often difficult to define. This leaves open the possibility that the GJ might be both more and maybe less than a movement of militant populism. History and hindsight may transform some of these possibilities into certainties. For the moment, the rise of the GJ presents one case in the many collective struggles that have emerged at a political and economic conjuncture when savage capitalism prevails. Attempt to illuminate the specific contours of such movements at specific

\footnotetext{
$\overline{22}$ https://www.lexpress.fr/actualite/politique/gilets-jaunes-une-jacquerie-moderne_2048798. html

${ }^{23} \mathrm{https}$ //www.huffingtonpost.fr/michel-pigenet/ce-qui-peut-fragiliser-le-mouvement-des-giletsjaunes a $23591515 /$

${ }_{24}$ Kouvelakis, (2019)
} 
conjuncture political and economic forces will also offer up possibilities and insights into how grievances of ordinary people might be addressed.

\section{References}

Antoine Artous and Francis Sitel (2019) Yellow vest: what horizons for anger http://www.contretemps.eu/giletsjaunes-horizon-colere/.

Berger, S. 2017. Populism and the failures of representation. French Politics, Culture \& Society 35 (2): 21-31.

Bonikowski, Bart, and Noam Gidron. 2016. The populist style in American politics: presidential campaign discourse, 1952-1996. Social Forces 94: 4.

Fitzgerald, S. 1970. The anti-modern rhetoric of le movement Poujade. The Review of Politics 32 (2): 167-190.

Fourcade- Gourchinas, Marion and Sarah Babb. 2002. The rebirth of the liberal creed: paths to neo-liberalism in four countries. American Journal of Sociology 108 (3): 533-579.

Fraser, Nancy. 2017. A new form of capitalism? A reply to Boltanski and Esquerre. Pp. 57-65.

Harris, O., and K. Young. 1981. Engendered structures: some problems in the analysis of reproduction. The anthropology of pre-capitalist societies: 109-147.

Harvey, D. 2012. Rebel cities: from the right to the city to the urban revolution. Verso books.

Harvey, D., and R. Williams. 1995. Militant particularism and global ambition: the conceptual politics of place, space, and environment in the work of Raymond Williams. Social Text 42: 69-98.

Hoffmann, S., Des Accords, M., Hurtig, S., Du Rostu, J., \& Meynaud, J. (1956). Le mouvement Poujade. Avec la collab. de. Des Accords, S. Hurtig, J. Du Rostu,[ea]. Préf. de J. Meynaud. Colin.

Katz, C. 2001. Vagabond capitalism and the necessity of social reproduction. Antipode 33 (4): 709-728.

Kouvelakis, S. 2019. The French insurgency political economy of the gilets Jaunes. New Left Review 116: 75-98.

Lefebvre, H. 2003. The urban revolution. U of Minnesota Press.

Lem, Winnie. 1999. Cultivating dissent: work, identity, and praxis in rural Languedoc. SUNY Press.

Mayer, N., Rockhill, G., Hayat, S., Pal, M., Marlière, P., Mischi, J., ... \& Johnstone, D. (2019). One question: gilets jaunes [What is the significance of the Gilets Jaunes movement?].

Paye, J.C. 2019. The yellow vests in France people or proletariat? Monthly review. E 71 (2): 49-59.

Prasad, Monica. 2005. Why is France so French? Culture, institutions, and neoliberalism. American Journal of Sociology 111 (2): 357-407.

Shields, J.G. 2004. An enigma still: Poujadism fifty years on. French Politics, Culture \& Society, 22(1), 36-56.

Smith, Timothy B. 2004. France in crisis: welfare, inequality, and globalization since 1980. Cambridge: Cambridge University Press.

Susser, Ida (forthcoming) Social transformation, commoning and urban ethics: Nuit Debout, The Gilets Jaunes and other contentious performances.

Tilly, Charles. 1986. The contentious French: four centuries of popular struggle. Cambridge: Harvard University Press.

Wilkin, Peter. 2018. Rip it up and start again: the challenge of populism in the twenty-first century. Journal of World-Systems Research 24 (2): 314-324.

Wilkin, P. 2020. Fear of a yellow planet: the gilets Jaunes and the end of the modern world-system. Journal of World-Systems Research 26 (1): 70-102.

Publisher's note Springer Nature remains neutral with regard to jurisdictional claims in published maps and institutional affiliations. 